\title{
Właściwości złączy spawanych wykonanych elektrodami zasadowymi i celulozowymi
}

\section{Properties of basic and cellulose electrode welded joints}

\section{Streszczenie}

W artykule przedstawiono wyniki badań kwalifikowania technologii spawania stali o podwyższonej wytrzymałości elektrodami z otuliną celulozową, zasadową oraz metodą łączoną - przetop elektroda celulozowa, warstwy wypełniające - elektroda zasadowa. Dokonano porównania właściwości wytrzymałościowych oraz przedstawiono wyniki badań mikroskopowych obrazujące zmiany mikrostruktury złączy w zależności od rodzaju zastosowanej technologii spawania.
Abstract

The article presents the results of the qualification of welding high strength steel by cellulose, basic and combined method - penetration by cellulose electrode and fill layers - a basic electrode. A comparison of mechanical properties and the results of microscopic testing of the microstructure of joints depending on the type of technology used for welding is presented.

\section{Wstęp}

Spawanie łukowe ręczne elektrodą otuloną, dzięki uniwersalności techniczno-technologicznej, umożliwia wykonanie połączeń o wysokich właściwościach eksploatacyjnych prawie wszystkich metalowych tworzyw konstrukcyjnych w dowolnej pozycji i trudno dostępnych miejscach. Duży wybór gatunków elektrod otulonych umożliwia spawanie stali niskowęglowych, niskostopowych o wysokiej wytrzymałości, stali specjalnych wysokostopowych, nadstopów, staliwa, żeliw szarych i sferoidalnych oraz miedzi, niklu, aluminium i ich stopów [1]. Możliwe jest również wykonanie połączeń metali i stopów różniących się znacznie właściwościami fizycznymi, np. stali węglowej ze stalą austenityczną, stali wysokostopowych z miedzią, itd. Niemożliwe jest natomiast spawanie metali, których osłona łuku elektrod otulonych nie wystarcza do zapewnienia odpowiedniej ochrony przed dostępem gazów $z$ atmosfery (tytan, cyrkon, wolfram, niob, tantal i molibden) [1].

Spawanie ręczne elektrodą otuloną jest technologią, która wbrew opinii niektórych środowisk jest i będzie nadal stosowana, a wspólnie $z$ technologią spawania

Dr inż. Ryszard Pakos - Zachodniopomorski Uniwersytet Technologiczny w Szczecinie. drutami proszkowymi jest bardzo rozpowszechniona przy wytwarzaniu odpowiedzialnych konstrukcji morskich (platformy wiertnicze) oraz trudniejszych odcinków rurociągów przemysłowych ropy lub gazu. Duży wybór gatunków elektrod otulonych dostępnych obecnie na rynku umożliwia technologom spawalnikom dobór odpowiednich rozwiązań dla danej konstrukcji. Najbardziej rozpowszechnione i uniwersalne są elektrody o otulinie zasadowej. W warunkach montażowych wytwórcy konstrukcji stalowych chętnie sięgają też po elektrody celulozowe, które mają zastąpić metodę TIG na warstwach przetopowych.

W tablicy I zestawiono właściwości elektrod o otulinie zasadowej i celulozowej, natomiast w tablicy II porównano właściwości mechaniczne tych elektrod.

Elektrody celulozowe mają ograniczone zastosowanie do wykonywania konstrukcji pracujących w niskich temperaturach. Praktycznie nie można nimi spawać elementów obciążonych dynamicznie, gdyż powoduje to niebezpieczeństwo wystąpienia pęknięć kruchych, wynikające $z$ dużej zawartości wilgoci w stopiwie tych elektrod. Wilgoć ta nie może być usunięta, gdyż spawanie elektrodą celulozową o suchej otulinie jest praktycznie niemożliwe ze względu na niestabilny, strzelający łuk i dużą ilość wyrzucanego materiału z jeziorka spawalniczego, co powoduje w tych warunkach tworzenie się głębokich podtopień, stanowiących miejsce gromadzenia się żużli, 
Tablica I. Porównanie cech elektrod zasadowych i celulozowych [2, 3]

Table I. Comparison of features of basic and cellulosic electrodes [2, 3]

\begin{tabular}{|c|c|c|}
\hline $\begin{array}{l}\text { Porównywana } \\
\text { cecha }\end{array}$ & Elektrody z otuliną zasadową & Elektrody z otuliną celulozową \\
\hline $\begin{array}{l}\text { Główne } \\
\text { składniki } \\
\text { otuliny }\end{array}$ & $\begin{array}{l}\text { węglan wapnia }\left(\mathrm{CaCO}_{3} \text {, }\right) \text { dostarczany do otuliny pod po- } \\
\text { stacią kredy i marmuru) } \\
\text { węglan magnezu, fluoryt }\left(\mathrm{CaF}_{2}\right)\end{array}$ & $\begin{array}{l}\text { celuloza } \\
\text { mączka drzewna } \\
\text { skrobia }\end{array}$ \\
\hline $\begin{array}{l}\text { Łuk } \\
\text { elektryczny }\end{array}$ & $\begin{array}{l}\text { pierwiastki o małym potencjale jonizacji ( } \mathrm{Na}, \mathrm{Ca}, \mathrm{Mg}) \\
\text { stabilizują jarzenie się łuku } \\
\text { łuk zajarza się łatwo, jest elastyczny }\end{array}$ & $\begin{array}{l}\text { łuk ma wysoką temperaturę, która ułatwia uzyskanie głębo- } \\
\text { kiego wtopienia, mało elastyczny w przypadku suchej otu- } \\
\text { liny }\end{array}$ \\
\hline $\begin{array}{l}\text { Charakter } \\
\text { stapiania } \\
\text { elektrody }\end{array}$ & $\begin{array}{l}\text { elektroda stapia się stabilnie, występuje mała } \\
\text { liczba odprysków, charakter przejścia metalu w łuku } \\
\text { jest grubokroplowy,niskie zadymienie w czasie } \\
\text { spawania ułatwia obserwację jeziorka spawalniczego } \\
\text { oraz pracę w pomieszczeniach/ konstrukcjach } \\
\text { o ograniczonej wentylacji }\end{array}$ & $\begin{array}{l}\text { elektroda topi się stabilnie, gdy utrzymywany jest krótki łuk } \\
\text { kierowany na jeziorko, a zawartość wody w otulinie wynosi } \\
\text { co najmniej } 3 \% \text {, odstępstwa powodują powstawanie dużej } \\
\text { ilości odprysków i głębokich podtopień, } \\
\text { w czasie spawania wydziela się dużo dymów w wyniku } \\
\text { wypalania składników organicznych otuliny, co znacznie } \\
\text { utrudnia spawanie w miejscach o ograniczonej wentylacji }\end{array}$ \\
\hline Wygląd spoin & $\begin{array}{l}\text { spoiny mają płaski, regularny kształt, również po spawa- } \\
\text { niu w pozycjach przymusowych }\end{array}$ & $\begin{array}{l}\text { płaski kształt spoin przy spawaniu w pozycji PA i PG, po } \\
\text { spawaniu w pozycji PF ściegi są nieregularne, występuje } \\
\text { nadmierny nadlew }\end{array}$ \\
\hline $\begin{array}{l}\text { Pozycje spa- } \\
\text { wania }\end{array}$ & $\begin{array}{l}\text { wszystkie z wyjątkiem PG, dla której stosuje się otuliny } \\
\text { o zmodyfikowanym składzie }\end{array}$ & $\begin{array}{l}\text { możliwe jest wykonywanie spoin we wszystkich pozycjach, } \\
\text { jednak spawanie w pozycjach przymusowych jest utrudnio- } \\
\text { ne ze względu na dużą ilość odprysków }\end{array}$ \\
\hline Zastosowanie & $\begin{array}{l}\text { spawanie blach o grubych przekrojach w sztywnych kon- } \\
\text { strukcjach, spawanie stali o ograniczonej spawalności, } \\
\text { spawanie stali o zwiększonej ilości węgla }\end{array}$ & $\begin{array}{l}\text { zastosowanie prawie wyłącznie do spawania opadowego } \\
\text { rurociągów }\end{array}$ \\
\hline $\begin{array}{l}\text { Odporność } \\
\text { na pękanie }\end{array}$ & $\begin{array}{l}\text { pęknięcia zimne: wysoka odporność wskutek minimali- } \\
\text { zowania ilości wilgoci w otulinie w wyniku suszenia, } \\
\text { pęknięcia gorące: wysoka odporność wynikająca } \\
\text { z wysokiej czystości metalurgicznej stopiwa }\end{array}$ & $\begin{array}{l}\text { pęknięcia zimne: duża skłonność w przypadku grubych } \\
\text { przekrojów spawanych wynikająca z nieusuwalnej ilości } \\
\text { wprowadzonego wodoru do stopiwa, pochodzi on } \\
\text { z rozkładu wilgoci w łuku elektrycznym, } \\
\text { pęknięcia gorące: stal skłonna w przypadku obecności } \\
\text { siarki w stopiwie }\end{array}$ \\
\hline Suszenie & $\begin{array}{l}300 \div 350^{\circ} \mathrm{C} \text { przez ok. } 1 \div 3 \mathrm{~h} \text {, po wysuszeniu możliwe } \\
\text { przechowywanie w termosach przez } 8 \mathrm{~h}\end{array}$ & elektrod celulozowych nie suszy się \\
\hline
\end{tabular}

a w konsekwencji przyklejeń. Niezależnie jednak od wymienionych trudności, zastosowanie elektrod celulozowych w warunkach montażowych ma wiele zalet:

- możliwość spawania we wszystkich pozycjach, szczególnie pionowej z góry na dół,

- łatwość wykonania warstwy graniowej,

- możliwość wykonania ściegów przetopowych elektrodami o średnicy $4 \mathrm{~mm}$ i większej,

- mniejszą wrażliwość na dokładność przygotowania złącza,

- małą wrażliwość na warunki atmosferyczne,

- dużą wydajność spawania.

Tablica II. Porównanie właściwości mechanicznych elektrod zasadowych i celulozowych [2, 3]

Table II. Comparison of mechanical properties of basic and cellulosic electrodes [2, 3]

\begin{tabular}{|l|c|c|c|c|c|}
\hline \multirow{2}{*}{ Elektroda } & \multirow{2}{*}{$\begin{array}{c}\text { Rodzaj } \\
\text { otuliny }\end{array}$} & \multicolumn{5}{|c|}{ Wielkość mechaniczna } \\
\cline { 3 - 6 } & $\mathrm{R}_{\mathrm{e}}, \mathrm{MPa}$ & $\mathrm{A}_{5}, \%$ & $\mathrm{KV}, \mathrm{J}$ & $\mathrm{R}_{\mathrm{m}}, \mathrm{MPa}$ \\
\hline Celex & $\mathrm{C}$ & $>390$ & $>22$ & $>70\left(+20^{\circ} \mathrm{C}\right)$ & $450 \div 550$ \\
\hline Celex Mn & $\mathrm{C}$ & $>420$ & $>20$ & $>70\left(+20^{\circ} \mathrm{C}\right)$ & $540 \div 610$ \\
\hline Fleetweld 5P & $\mathrm{C}$ & $>420$ & $>26$ & $>60\left(-20^{\circ} \mathrm{C}\right)$ & $500 \div 640$ \\
\hline EB 150 & $\mathrm{B}$ & $>420$ & $22-32$ & $>65\left(-40^{\circ} \mathrm{C}\right)$ & $550 \div 620$ \\
\hline OK 48.08 & $\mathrm{B}$ & $>490$ & $>30$ & $160\left(-20^{\circ} \mathrm{C}\right)$ & $>575$ \\
\hline OK 40.00 & $\mathrm{B}$ & $>445$ & $>29$ & $140\left(-20^{\circ} \mathrm{C}\right)$ & $>540$ \\
\hline
\end{tabular}

\section{Badania własne}

Celem przeprowadzonych badań było określenie i porównanie właściwości złączy spawanych, wykonanych ze stali EH36 o grubości 16 mm elektrodami zasadowymi (E424B42) oraz celulozowymi (Fleetweld5P - E422C25). Charakterystykę materiału podstawowego oraz elektrody celulozowej przedstawiono w [11], natomiast elektrody zasadowej w tablicy III.

Złącza próbne wykonano zgodnie z przygotowanymi wstępnie instrukcami technologicznymi spawania (pWPS) na podstawie normatywów technologicznych i zaleceń producenta materiałów dodatkowych. W celu pełnej identyfikacji złączy wprowadzono oznaczenia płyt próbnych przedstawione $\mathrm{w}$ tablicy IV, które będą wiążące $w$ dalszych badaniach.

Płyta próbna 1C-PF została wykonana w całości przy użyciu elektrod celulozowych. Charakterystyczną cechą, którą zaobserwowano przy wykonywaniu tego złącza, był sposób zachowania się łuku. Elektroda topiła się stabilnie w przypadku krótkiego łuku, jednak duża zawartość wody w otulinie (ok. $3 \%$ ) powodowała powstawanie dużej ilości rozprysków i głębokich podtopień na ściankach rowka spawalniczego. Nieusuwanie tych podtopień skutkowało zaleganiem w nich żużla, a w konsekwencji możliwością pojawienia się 
przyklejeń. Dlatego po wykonaniu każdego ściegu należało dokładnie zeszlifować pozostałe niezgodności, co w praktyce zwiększyło liczbę zaplanowanych ściegów i wprowadziło dużo ciepła do złącza spawanego. Widok warstwy graniowej i drugiej warstwy przedstawiono na rysunku 1.

Taka technologia spawania niekorzystnie wpłynęła na geometrię rowka, powodując jego cykliczne poszerzanie aż do warstwy licowej. W rezultacie zaobserwowano znaczne odkształcenia kątowe płyty próbnej, mimo zastosowania klamer montażowych. Technologia spawania płyty próbnej 2CB-PF zakładała wykonanie ściegu graniowego elektrodą celulozową, natomiast pozostałych ściegów - elektrodą zasadową.

Tablica III. Charakterystyka elektrody zasadowej E424B42 [9] Table III. Characteristic of basic electrode E424B42 [9]

\begin{tabular}{|c|c|c|}
\hline Klasyfikacja & \multicolumn{2}{|c|}{$\begin{array}{l}\text { PN- EN 499: E } 424 \text { B } 42 \\
\text { AWS A5.1: E7018 }\end{array}$} \\
\hline $\begin{array}{l}\text { Ogólna } \\
\text { charakterystyka }\end{array}$ & \multicolumn{2}{|c|}{$\begin{array}{l}\text { Grubo otulona elektroda do spawania kon- } \\
\text { strukcji ze stali o podwyższonej wytrzyma- } \\
\text { łości narażonych na duże obciążenia sta- } \\
\text { tyczne i dynamiczne (konstrukcje okręto- } \\
\text { we, tabor komunikacyjny, maszyny budow- } \\
\text { lane itp.) } \\
\text { Umożliwia wykonywanie spoin pachwino- } \\
\text { wych w pozycji pionowej z góry na dół. }\end{array}$} \\
\hline Pozycje spawania & \multicolumn{2}{|c|}{ PA, PB, PC, PE, PF, PG } \\
\hline $\begin{array}{l}\text { Prąd spawania } \\
\text { i biegunowość }\end{array}$ & \multicolumn{2}{|c|}{ stały $(+)$ do elektrody } \\
\hline \multirow{3}{*}{$\begin{array}{l}\text { Typowy } \\
\text { skład stopiwa }\end{array}$} & C & 0,08 \\
\hline & $\mathrm{Mn}$ & 1,1 \\
\hline & $\mathrm{Si}$ & 0,4 \\
\hline \multirow{4}{*}{$\begin{array}{l}\text { Typowe } \\
\text { właściwości } \\
\text { mechaniczne }\end{array}$} & $\mathrm{R}_{\mathrm{e}}$ & $>420$ \\
\hline & $R_{m}$ & $550-620$ \\
\hline & $\mathrm{A}_{5}$ & $>22-32$ \\
\hline & $\mathrm{KV}[\mathrm{J}]-40$ & $>65$ \\
\hline Dopuszczenia & \multicolumn{2}{|c|}{$\begin{array}{l}\text { UDT, TÜV, BD-U } \\
\text { PRS kat. } 3 \text { YH-10 } \\
\text { LRS kl. 3,3Y, H15 } \\
\text { BV kl. } 3 \text { YHH } \\
\text { DNV kl. } 3 \text { YH10 } \\
\text { GL kl. } 3 \text { YHH } \\
\text { ABS kl. } 3 \text { Y, } 3 \mathrm{H} 10\end{array}$} \\
\hline
\end{tabular}

Tablica IV. Oznaczenie płyt próbnych

Table IV. Sample plate designation

\begin{tabular}{|l|l|}
\hline $\begin{array}{c}\text { Oznaczenie } \\
\text { płyty próbnej }\end{array}$ & \multicolumn{1}{|c|}{ Uwagi } \\
\hline 1C-PF & $\begin{array}{l}\text { Pozycja spawania PF, ścieg graniowy, wy- } \\
\text { pełniający i lico wykonane elektrodami ce- } \\
\text { lulozowymi }\end{array}$ \\
\hline 2BC-PF & $\begin{array}{l}\text { Pozycja spawania PF, ścieg graniowy wyko- } \\
\text { nany elektrodami celulozowymi, ściegi wy- } \\
\text { pełniające i lico spawane przy użyciu elektrod } \\
\text { zasadowych }\end{array}$ \\
\hline 3B-PF & $\begin{array}{l}\text { Pozycja spawania PF, ścieg graniowy, wy- } \\
\text { pełniający i lico wykonane elektrodami za- } \\
\text { sadowymi }\end{array}$ \\
\hline
\end{tabular}
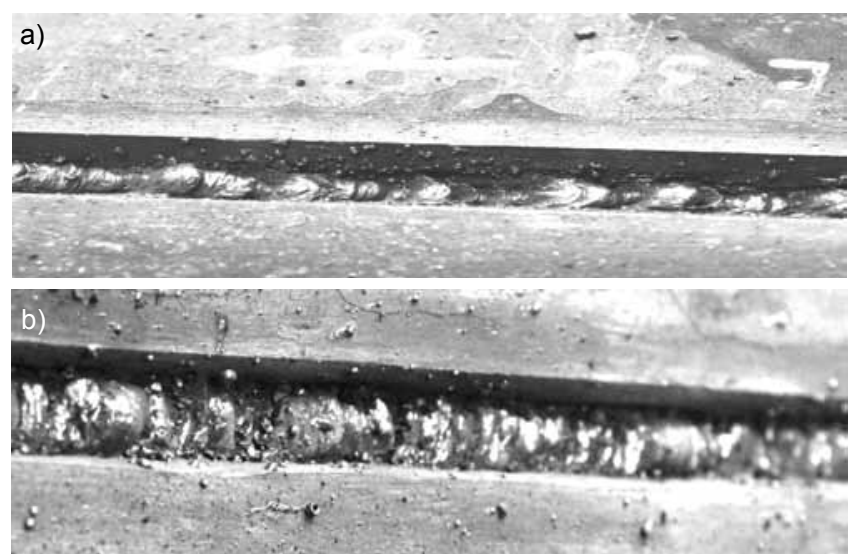

Rys. 1. Złącze wykonane elektrodą celulozową: a) ścieg graniowy, b) druga warstwa, widoczne żużle spawalnicze na brzegach rowka

Fig. 1. Joint made by cellulose electrode: a) reverse-side bead, b) second layer, visible slag on the banks of welding groove

Nie odnotowano większych trudności przy wykonywaniu tego złącza, poza ściegiem graniowym, który wykazywał cechy opisane powyżej.

Złącze próbne 3B-PF wykonano w całości elektrodami zasadowymi. Przed rozpoczęciem spawania wysuszono elektrody w temperaturze $250 \div 300^{\circ} \mathrm{C}$. Ze względu na mniejsze wtopienie elektrod zasadowych w stosunku do elektrod celulozowych, zastosowano szerszy odstęp między blachami. Po wykonaniu złącza otrzymano pełny przetop na całej długości, a jakość ściegu graniowego i ściegów wypełniających była zadowalająca i nie wykazywały one tendencji do tworzenia podtopień na ściankach rowka, ani też nadmiernej ilości rozprysków.

Badania technologii spawania przeprowadzono zgodnie z wymaganiami Polskiego Rejestru Statków zamieszczonymi w Publikacji Nr 74/P [6].

Rozmieszczenie próbek do badań niszczących przedstawiono na rysunku 2.

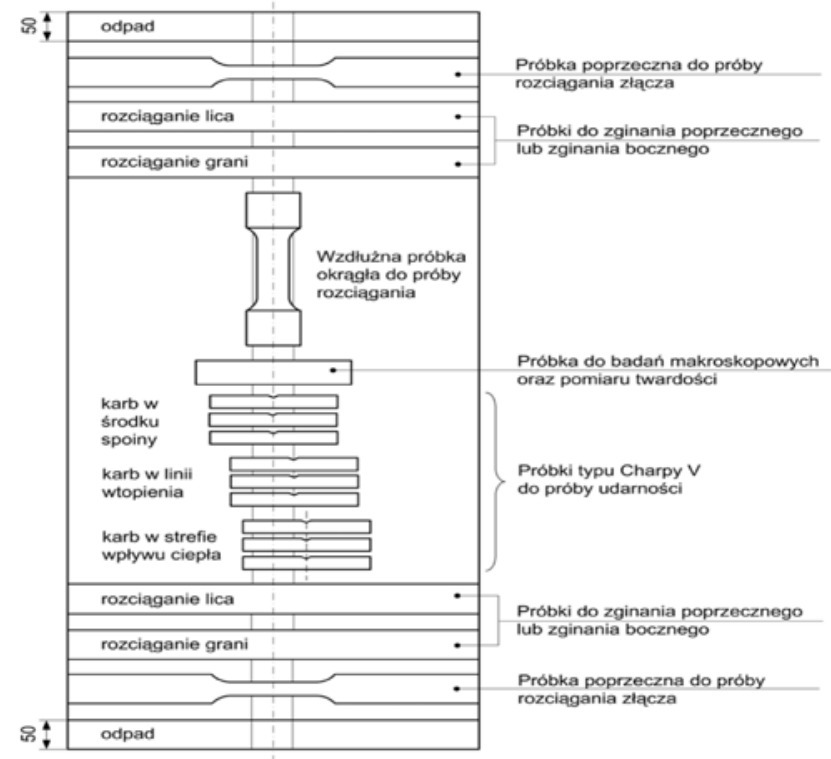

Rys. 2. Rozmieszczenie próbek do badań niszczących [6, 11]

Fig. 2. Arrangement of samples for destructive testing $[6,11]$ 


\section{Wyniki badań}

Przeprowadzone badania wizualne, magnetyczno-proszkowe oraz radiograficzne nie wykazały niedopuszczalnych niezgodności spawalniczych. Osiągnięto poziom jakości B i poziomy akceptacji 1.

Badania makroskopowe przeprowadzono zgodnie z PN-EN1321. Wytrawione odczynnikiem Adlera zgłady przedstawiono na rysunku 3.

Jak wynika $z$ tego rysunku we wszystkich próbach osiągnięto pełny przetop oraz nie zaobserwowano niedopuszczalnych niezgodności spawalniczych, z wyjątkiem dużego odkształcenia kątowego (płyta 1C-PF) w przypadku wykonania całej płyty elektrodami celulozowymi.

Cechą charakterystyczną przedstawionych zgładów metalograficznych są różnice wysokości grani, szerokości stref wpływu ciepła oraz liczby ściegów na przekroju złącza. W tablicy $\vee$ przedstawiono charakterystyczne wielkości uzyskane w wyniku badań makroskopowych.

Wyniki badań wskazują, że najbardziej narażone na szkodliwe działanie ciepła są złącza wykonane elektrodami celulozowymi. Szlifowanie po spawaniu
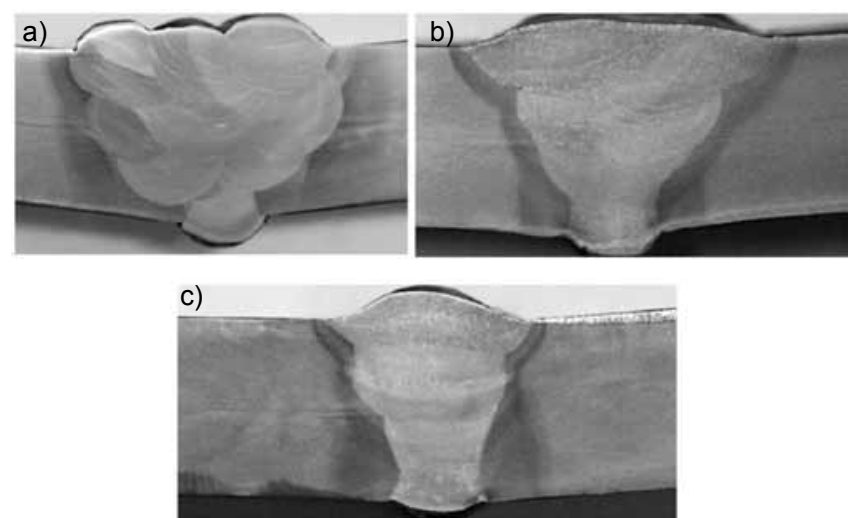

Rys. 3. Makrostruktura złączy: a) 1C-PF, b) 2CB-PF, c) 3B-PF Fig. 3. Macrostructure of joints: a) 1C-PF, b) 2CB-PF, c) 3B-PF

Tablica V. Liczba ściegów i pola powierzchni SWC Table V. Number of beads and the SWC area

\begin{tabular}{|l|c|c|}
\hline $\begin{array}{l}\text { Oznaczenie płyty, z któ- } \\
\text { rej został pobrany zgład }\end{array}$ & Liczba ściegów & $\begin{array}{c}\text { Powierzchnia } \\
\text { SWC, } \mathrm{mm}^{2}\end{array}$ \\
\hline $1 \mathrm{C}-\mathrm{PF}$ & 11 & 171 \\
\hline $2 \mathrm{CB}-\mathrm{PF}$ & 7 & 114 \\
\hline $2 \mathrm{~B}-\mathrm{PF}$ & 4 & 94 \\
\hline
\end{tabular}

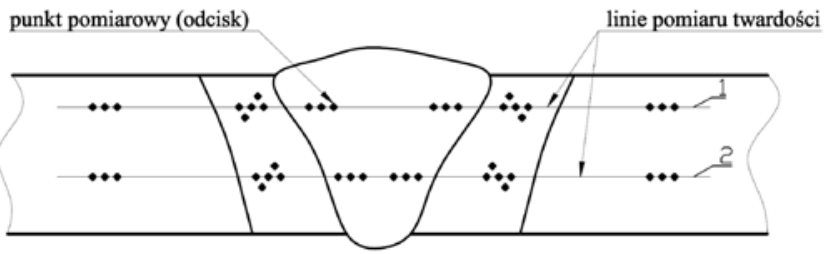

Rys. 4. Miejsca pomiaru twardości

Fig. 4. The places of hardness testing
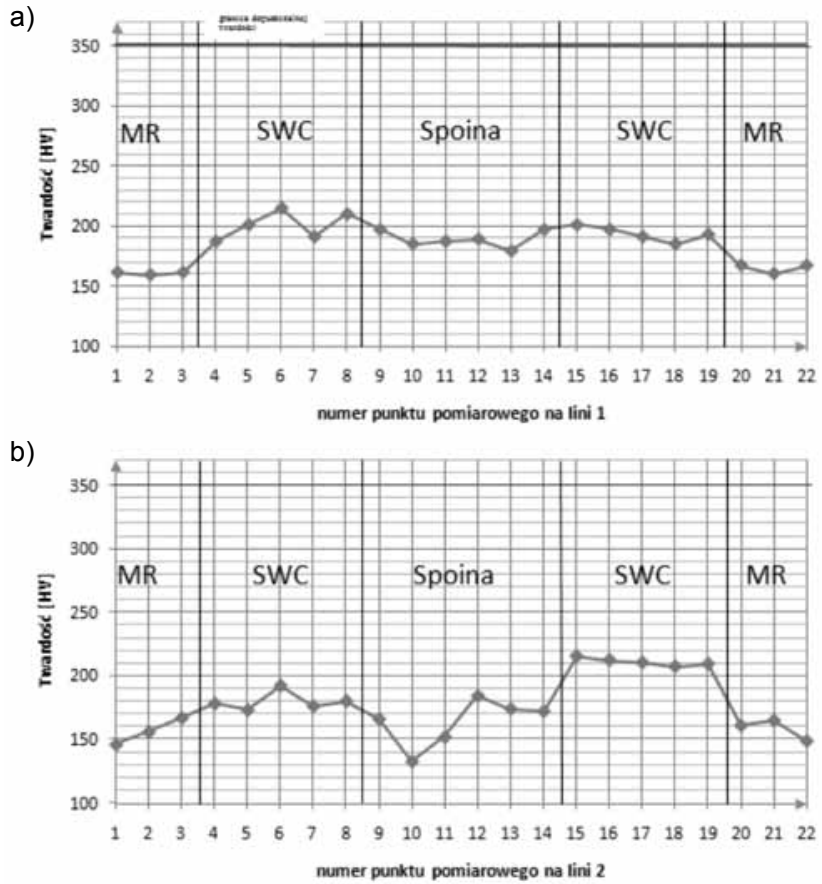

Rys. 5. Rozkład twardości w złączu wykonanym elektrodą celulozową i zasadową: a) 1. linia pomiarowa, b) 2. linia pomiarowa

Fig. 5. Distribution of hardness in the joint made by cellulose and basic electrode: a) 1. measurement line, b) 2. measurement line

powoduje zmniejszanie przekroju wykonanego ściegu, co doprowadza do ponownego wnikania ciepła w wykonany obszar złącza. Efektem końcowym jest duża liczba ściegów i wyraźny rozrost szerokości strefy wpływu ciepła.

Badania twardości przeprowadzono twardościomierzem LECO LV 700AT zgodnie z normami PN-EN1043-1 i PN-EN ISO 6507-1. Pomiary na dwóch liniach pomiarowych wykonano zgodnie z rysunkiem 4.

Wyniki badań uznaje się za pozytywne, jeżeli uzyskana twardość nie przekracza $350 \mathrm{HV} 10$ dla stali o $R_{\text {eH }} \leq 420 \mathrm{MPa}$ i $420 \mathrm{HV} 10$ dla stali o $420 \mathrm{MPa}$ $<\mathrm{R}_{\mathrm{eH}}<690 \mathrm{MPa}$ [6]. Uzyskane wyniki badań dla elektrody celulozowej przedstawiono w [11], na rysunku 5 pokazano rozkład twardości złączy wykonanych elektrodą celulozową i zasadową, a na rysunku 6 tylko elektrodą zasadową.

Stal EH36 jest stalą kadłubową o podwyższonej wytrzymałości z minimalną granicą plastyczności $\mathrm{R}_{\mathrm{eH}}=355 \mathrm{MPa}$, stąd też zgodnie $\mathrm{z}$ wymaganiami, maksymalna twardość w złączu spawanym nie może przekroczyć 3650 HV10 [6].

Badania udarności przeprowadzono zgodnie $z$ normą PN-EN10045-1 na próbkach typu Charpy V szerokości $10 \mathrm{~mm}$. Do prób pobrano po 3 zestawy z każdej płyty próbnej (karb nacięto w środku spoiny, w linii wtopienia oraz w SWC w odległości $2 \mathrm{~mm}$ od linii wtopienia). Próbę wykonano $w$ temperaturze $-20^{\circ} \mathrm{C}$. Wyniki badań przedstawiono na rysunku 7 . 
a)

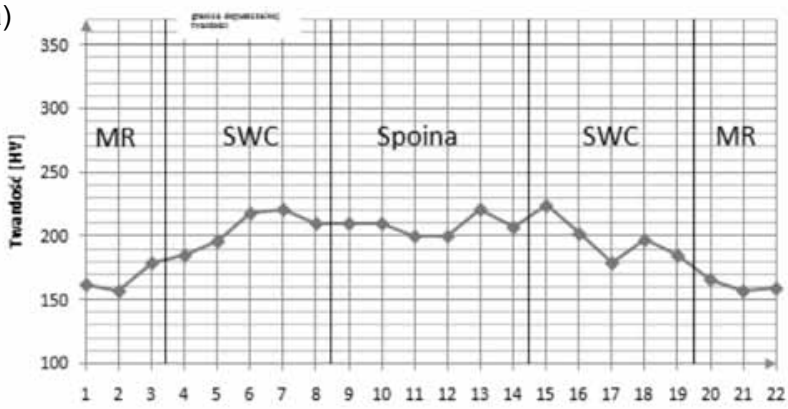

b)

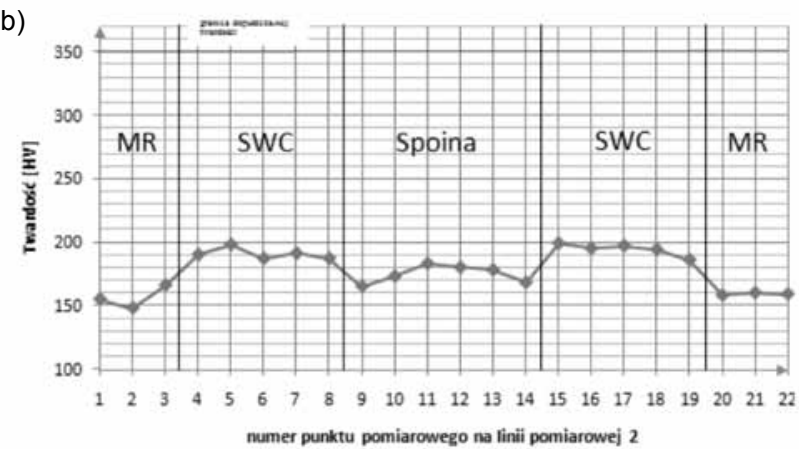

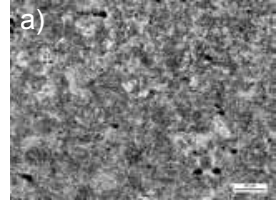
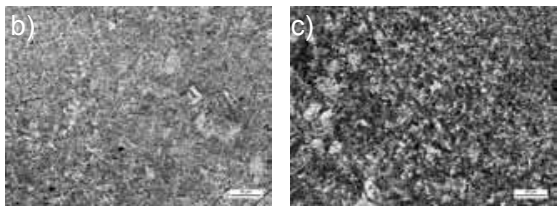

Rys. 8. Strefa przegrzania na wysokości górnych ściegów, trawienie - nital, pow. 500x: a) 1C-PF, b) 2BC-PF, c) 3B-PF

Fig. 8. Heat affected zone in the upper beads; etching: nital, magnification 500x: a) 1C-PF, b) 2BC-PF, c) 3B-PF
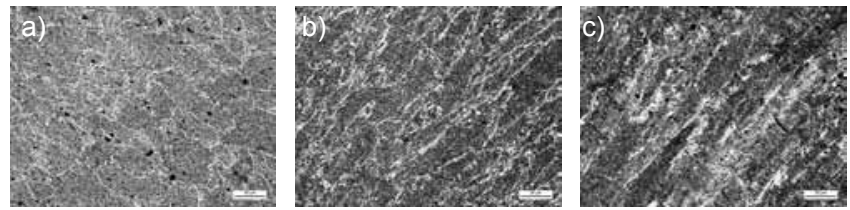

Rys. 9. Strefy kryształów dendrytycznych, trawienie - nital, pow. 500x: a) 1C-PF b) 2BC-PF c) 3B-PF

Fig. 9. Zone with dendritic crystals etching; nital, magnification 500x: a) $1 \mathrm{C}-\mathrm{PF}$, b) $2 \mathrm{BC}-\mathrm{PF}, \mathrm{c}) 3 \mathrm{~B}-\mathrm{PF}$

Negatywny wynik badania udarności uzyskała próba z płyty wykonanej elektrodą celulozową pobrana w linii wtopienia (rys. 7). $Z$ tego powodu wykonano dodatkowe badania mikroskopowe w celu wyjaśnienia tak dużego spadku udarności w linii wtopienia przy licu spoiny. Na rysunku 8 przedstawiono strefy przegrzania płyt próbnych, natomiast na rysunku 9 pokazano obrazy stref kształtów dendrytycznych, które stykają się bezpośrednio z liniami wtopienia.

Silny rozrost ziarna (rys. 8a), jak również słabo rozbudowane dendryty (rys. 9a) świadczą o dużej ilości ciepła wprowadzonego do złącza w czasie spawania płyty elektrodą celulozową. Tym też należy tłumaczyć gwałtowny spadek udarności w linii wtopienia przy wykonywaniu złączy elektrodami celulozowymi.

\section{Wnioski}

- Elektrody celulozowe ze względu na swoje właściwości nadają się do wykonywania warstw przetopowych w trudnych warunkach przemysłowych.

- Elektrody celulozowe nie wymagają suszenia zalecana zawartość wilgoci w otulinie wynosi ok. $3 \%$.

- Łuk elektryczny na wilgotnych otulinach celulozowych wykazuje tendencje do głębokich penetracji i zawirowań, co odbija się głębokimi

podtopieniami na ściankach rowka, a w konsekwencji powoduje zaleganie żużli i niebezpieczeństwo pojawienia się przyklejeń.

- Niewskazane jest wykonywanie warstw wypełniających i licowych elektrodami celulozowymi, gdyż doprowadza to do znacznego zużycia elektrod i wydłuża czas wykonania złączy.

- Właściwości wytrzymałościowe złączy wykonanych elektrodami celulozowymi charakteryzują się spadkiem udarności w warstwach licowych na linii wtopienia. 


\section{Literatura}

[1] Klimpel A.: Technologia spawania i cięcia metali, Wydawnictwo Politechniki Śląskiej, Gliwice 1997.

[2] Szustakowski J.: Poradnik spawacza elektrycznego, WNT, Warszawa 1985

[3] Praca zbiorowa, Poradnik inżyniera Spawalnictwo część I, WNT, Warszawa 2005.

[4] Praca zbiorowa, Poradnik inżyniera Spawalnictwo część II, WNT, Warszawa 2005.

[5] PRS: Przepisy klasyfikacji i budowy statków morskich, Część IX - Materiały i spawanie, Gdańsk 2008
[6] PRS.: Publikacja P74-P, Zasady kwalifikowania technologii spawania, Gdańsk 2007.

[7] PN-EN 499:1997 Elektrody otulone do ręcznego spawania łukowego stali niestopowych i drobnoziarnistych.

[8] http://www.spawalnicze.com.pl/, 2009.

[9] www.esab.pl, 2009.

[10] www. lincoln- electric.pl, 2009.

[11] Pakos R.: Ocena technologii spawania stali o podwyższonej wytrzymałości elektrodą celulozową. Przegląd Spawalnictwa $4 / 2011$, s. $10-17$

\section{Sekcja Spawalnicza}

\section{Stowarzyszenie Inżynierów i Techników Mechaników Polskich Oddział Warszawski}

zaprasza na organizowane przez Sekcję Spawalniczą OW SIMP wszystkich członków SIMP i NOT na:

ODCZYTY TECHNICZNE

\begin{tabular}{|l|l|l|}
\hline Data i godzina & \multicolumn{1}{|c|}{ Prelegent, temat odczytu } & \multicolumn{1}{c|}{ Zakres tematyczny } \\
\hline $\begin{array}{l}\text { 12.05.2011 } \\
\text { godz. } 17^{00}\end{array}$ & $\begin{array}{l}\text { Mgr inż. JAN GRZEBALSKI } \\
\text { Nasze Spawalnictwo - DZIEN SPAWALNIKA }\end{array}$ & $\begin{array}{l}\text { Rys historyczny spawalnictwa Oddziału Warszawskiego } \\
\text { SIMP. Spotkanie okolicznościowe }\end{array}$ \\
\hline $\begin{array}{l}\text { 02.06.2011 } \\
\text { godz. 1700 }\end{array}$ & $\begin{array}{l}\text { Mgr inż. MAREK ŻUBROWSKI } \\
\text { Dyfuzja oraz powstawanie związków międzymetalicznych } \\
\text { w złączach drutowych AlSi1-Au }\end{array}$ & $\begin{array}{l}\text { Omówienie zjawiska dyfuzji oraz jej wpływu na stan } \\
\text { naprężeń własnych po procesie spajania drutowego }\end{array}$ \\
\hline
\end{tabular}

Gmach Stany Technologiczny Wydziału Inżynierii Produkcji Politechniki Warszawskiej, ul. Narbutta 86, sala nr ST145, dojazd tramwajami 10, 17 i 33

\section{WYCIECZKI TECHNICZNE}

\begin{tabular}{|l|l|l|}
\hline Data i godzina & \multicolumn{1}{|c|}{ Nazwa instytucji, adres } & Zakres zwiedzania / działalności \\
\hline $\begin{array}{l}\text { 16.06.2011 } \\
\text { godz. } 11^{00}\end{array}$ & $\begin{array}{l}\text { Centrum Nauki Kopernik } \\
\text { ul. Wybrzeże Kościuszkowskie 20 }\end{array}$ & Laboratoria, bilet wstępu: 22 zł. \\
\hline
\end{tabular}

\section{W imieniu Komitetu Organizacyjnego}

serdecznie zapraszamy wszystkich absolwentów Zakładu Inżynierii Spajania do uczestnictwa

\section{w Seminarium Zakładu Inżynierii Spajania połączonym ze zjazdem absolwentów \\ z okazji Jubileuszu 60-lecia Zakładu Inżynierii Spajania (dawniej Katedry/Zakładu Spawalnictwa) Politechniki Warszawskiej}

Osoby zainteresowane uczestnictwem w seminarium prosimy o kontakt: Seminarium odbędzie się 11.06.2011 r.
Zakład Inżynierii Spajania Politechnika Warszawska

ul. Narbutta 85 02-524 Warszawa tel.: 222348402 email: zis@wip.pw.edu.pl 